\title{
QUALITY ASSESSMENT OF BUSINESS STRATEGY IN INTERNATIONAL TRADE: INDICATORS AND PARAMETERS
}

\author{
Ilona Dumanska ${ }^{1}$
}

\begin{abstract}
The purpose of the paper is to develop a system of indicators and parameters for assessing the quality of business strategy in international trade based on analysis of the effectiveness of export-import operations, which are evaluated and analysed by managers in developing and implementing business strategies for effective management decisions to expand foreign markets. Methodology. There were used general scientific and special research methods. Assessing the quality of the company's business strategy in international trade when planning to enter or expand foreign markets was based on economic comparative analysis and grouping, synthesis and formalization. Using the method of coefficients, structural analysis and analytical comparison, groups of indicators are proposed for analysis and evaluation of the effectiveness of business strategy in export and import operations. Economic and mathematical modelling, scientific abstraction, systems analysis contributed to the development of economic parameters for assessing the quality of business strategy in international trade. Results. It is established that the assessment of the quality of the business strategy of the enterprise in international trade should be calculated not only taking into account absolute, relative, structural indicators, but also efficiency indicators. Groups of indicators for analysis and evaluation of the effectiveness of export and import operations that can be used in management activities are proposed. To determine the quality of business strategy in international trade, the feasibility of using the main block of efficiency indicators such as: direct effect of exports/imports, comparative effect of exports/ imports, the level of efficiency of exports/imports, and supplementing the block of indicators characterizing economic efficiency (end result) of the business strategy in international trade. An individual approach to the formation of each enterprise's own system of economic parameters for assessing the quality of business strategy in international trade, taking into account such basic parameters as assessing the scope of achieving business strategy goals, the importance of information data on business strategy assessment, timing of business assessment strategies, technical and methodological level of evaluation, novelty of the received information for adjustment of business strategy. Practical implications. Formation of a methodological approach to the assessment of such qualitative characteristics of business strategy in international trade as efficiency and effectiveness, determination of basic economic parameters of its evaluation system. Value/originality. The proposed groups of indicators and parameters for assessing the quality of business strategy in international trade can be used in management to confirm the effectiveness of strategic directions of business development and to counteract the making of intuitive decisions by top management in this area.
\end{abstract}

Key words: business strategy, international trade, quality indicators, system of indicators, system of parameters, economic effect, efficiency, foreign trade operations, export, import.

JEL Classification: M16, CO2, F14

\section{Introduction}

Domestic and foreign experience shows that most often the implementation of business strategies in international trade is carried out intuitively, based on empirical experience. At the same time, to make the right decisions, it is extremely necessary to systematize this process, identify its structure and qualitatively assess the effectiveness of actions. Steve Jobs said, "You

Corresponding author:

${ }^{1}$ Khmelnytskyi National University, Ukraine.

E-mail: dumanskaiy@gmail.com

ORCID: https://orcid.org/0000-0003-2449-0633

ResearcherID: Z-1244-2018 can't just ask consumers what they want and then try to give it to them. By the time you get it built, they'll want something new" (David, B. Yoffie and Michael A. Cusumano, 2015). Against the background of this statement there is understood the fluidity of quantitative aspects of strategic management, while indicators of the relevance of business strategy become appropriate due to quality parameters that are appropriate at all times. 
Evaluation as a stage of establishing the quality of business strategy in international trade is based on comprehensive information and consists in determining the possible consequences of the implementation of the chosen vector of action. Only one general indicator cannot evaluate business strategy, as it covers various areas of foreign economic activity. Evaluate the strategy on the quality of planned actions and the success of their implementation in each of the markets and supply centers of the sector "abroad". Sometimes the development of a business strategy for international trade requires a detailed assessment but its implementation does not yield the expected results (for example, poor management violated the term contracts for the supply of goods to a new country, resulting in financial sanctions and losses). In addition, the assessment of the chosen strategy is mainly carried out in the form of an analysis of the fidelity and adequacy of the factors that determine the feasibility of implementation and implementation of the strategy.

The main criterion for the quality of the chosen business strategy in international trade is the economic results of the organization in international markets for the sale of goods, and ultimately there is one procedure for evaluating the chosen strategy: whether the chosen strategy will achieve its goals. This is the main criterion for evaluating the chosen strategy, which is reflected in the performance of export and import operations.

Thus, to make effective management decisions, managers should analyse and evaluate business strategy in the field of international trade not only at the level of quantitative indicators: absolute, relative and structural, but also qualitative - performance indicators. It is important that the company has a system of indicators of quality assessment of business strategies in international trade, which would take into account the economic potential of the company, the specifics of its activities and the impact of internal and external factors (including market capacity) in order to achieve business strategy in the international trade.

\section{Methodology of research}

Among economists, scientists and managers, scientific interest in the concept, content of strategies, processes arose in the early 1960s, with A. Chandler's work "Strategy and Structure" (2001), which initiated the development of scientific thought and practice. The Harvard School responded to A. Chandler's ideas with the works of its professors, J. Bover and K. Christensen (1995) and others. It was at Harvard that one of the first strategic models, SWOT, was developed. The work of I. Ansoff (1989) contributed to the development of strategic management. Influenced by the work of M. Porter (1980), many researchers made their own developments in order to analyse the room for maneuvering the company without deviating from the outlined strategy.

The process of formation and implementation of competitive strategies of the organization aroused the interest of such foreign scholars as F. Wirsem and M. Tracy (1995), G. Mintzberg (1992), K. Prahalad and G. Hemel (1994) etc. These researchers proposed various definitions of the term "business strategy" and types of basic competitive strategies, described methods of their development and implementation in a developed economy.

Strategy theory has had a significant impact on international trade. Due to the fact that today there are no uniform methodological approaches to assessing the quality of business strategies in the field of international trade and the growing impact of integration processes, this issue requires more in-depth research. It is necessary to study the main economic parameters of international trade, which are evaluated and analysed by managers in the development and implementation of business strategies in this area and other functional units of the business entity to make effective management decisions to expand foreign markets.

\section{System of indicators for assessing business strategy in international trade}

The business strategy in the field of international trade of any business entity is a key means of gaining competitive advantage, as it creates an opportunity to use resources more efficiently and effectively, and to allocate investments by establishing new foreign economic relations. The whole system of assessing the quality of business strategy in international trade should be divided into four groups:

1. Absolute indicators: volume of exports; volume of imports; the amount of overhead costs for export/ import; average balance of funds; the number of complaints received; the amount of complaints; number of complaints satisfied; the volume of exports of new goods.

2. Relative indicators: dynamics index; cost index; physical volume index; price index; quantity index (for example, the dynamics of the share of world and European markets, the share of new goods in exports that have appeared in recent years, the share of cost reductions obtained due to the use of new technologies, etc.); coefficients of fulfillment of export/import obligations at cost, actual volume, price; average duration of turnover of export / import operation; return on funds from export/import operations.

3. Structural indicators: commodity structure of export/import; geographical structure; structure of overhead costs.

4. Performance indicators: currency efficiency of export/import; export/import efficiency; profitability 
of export/import; economic effect of exports/imports; integrated economic effect; efficiency of sales of export products on the domestic market; efficiency of purchase and use of imported equipment; efficiency of purchase and sale of licenses (Khomenko, Krush, 2019).

Thus, international trade, like any component of foreign economic activity, is evaluated through the values of quantitative indicators: absolute, relative and structural, and qualitative efficiency indicators. Economic efficiency is one of such indicators; it is defined as the efficiency of business strategy, which is characterized by the ratio of the economic effect obtained from its implementation to the cost of resources that led to this result (Shkvarchuk, Byrka, 2013).

Determining the effectiveness of business strategy in international trade determines the degree of interest of the company in entering the world market, allows to justify certain positions on the purchase and sale of certain products within the strategic actions of top management. The obtained data can be used in the development of export and import plans of the enterprise in assessing the structure and directions of foreign trade.

Thus, schematically, the system of indicators of business strategy in international trade of the enterprise in the subsystem of strategic management can be divided into four groups (Figure 1).

The system of indicators for evaluating business strategy in international trade is determined by the existing strategic guidelines of the business entity. If the company is only an intermediary in trade in products on foreign markets, the system of efficiency indicators will have a much smaller number of them, compared to the company that manufactures products and is actively involved in export and import operations. Efficiency refers to those economic parameters, the level of which is determined by certain criteria, and the efficiency indicator itself allows you to determine the approximation or already achieving the goals set by the company for the strategy of international trade.

Based on the fact that today there are a large number of possible indicators used to assess the level of effectiveness of business strategy in international trade of enterprises, it is necessary to identify the problematic aspects facing managers when systematizing groups of indicators of business strategy in international trade:

- significant differentiation of types of international trade leads to the presence of a significant number of indicators of processes in this area;

- defining the concept of efficiency of business strategy in international trade of the enterprise is quite controversial and there is no single paradigm for interpretation;

- there are different methods of calculating the effectiveness of business strategy in international trade; some are based on the definition of several economic parameters (indicators), others involve the use of economic and mathematical modeling with appropriate software;

- for the purpose of comparative analysis of the effectiveness of business strategy in international trade of individual enterprises there are no uniform guidelines and approaches to the formation of a subsystem of indicators to assess the effectiveness of business strategy in international trade of economic entities.

\section{Performance indicators in assessing the quality of business strategy in international trade}

At each enterprise, based on the peculiarities of its operating activities at the level of the parent unit and the vector of international trade in foreign markets, a system of indicators should be formed to determine the effectiveness of export and import operations of the entity in international trade. A clear substantiation of the effectiveness of international trade will create an opportunity to prevent unprofitable activities and timely make corrective management decisions within the established business strategy.

Today, there is no single system of economic efficiency indicators in the management of international trade business strategy; there is no consensus on the methods of calculation and methods of analysis of a number of indicators of the effectiveness of foreign trade operations. The groups of indicators selected by us for the analysis and evaluation of the effectiveness of the quality of business strategy in international trade are shown in Figure 2.

Thus, we can generalize that the economic efficiency of business strategy in international trade is a complex economic category; you can use a number of indicators to measure it. To determine the effectiveness of business strategy in international trade in the main block used general performance indicators of foreign trade operations of the enterprise:

- direct effect of exports (the difference between net sales rev enue for export and the cost of products intended for export; reflects the profit received from the implementation of the export transaction);

- comparative effect of exports (the difference between profits from export activities and profits from sales of similar products in the domestic market; shows the difference between profits from domestic and foreign markets, other things being equal);

- comparative effect of imports (the difference between the value of goods purchased in the domestic market and the value of goods purchased in the same amount in foreign markets; reflects the savings that the company receives through the purchase of goods in foreign and domestic markets); 


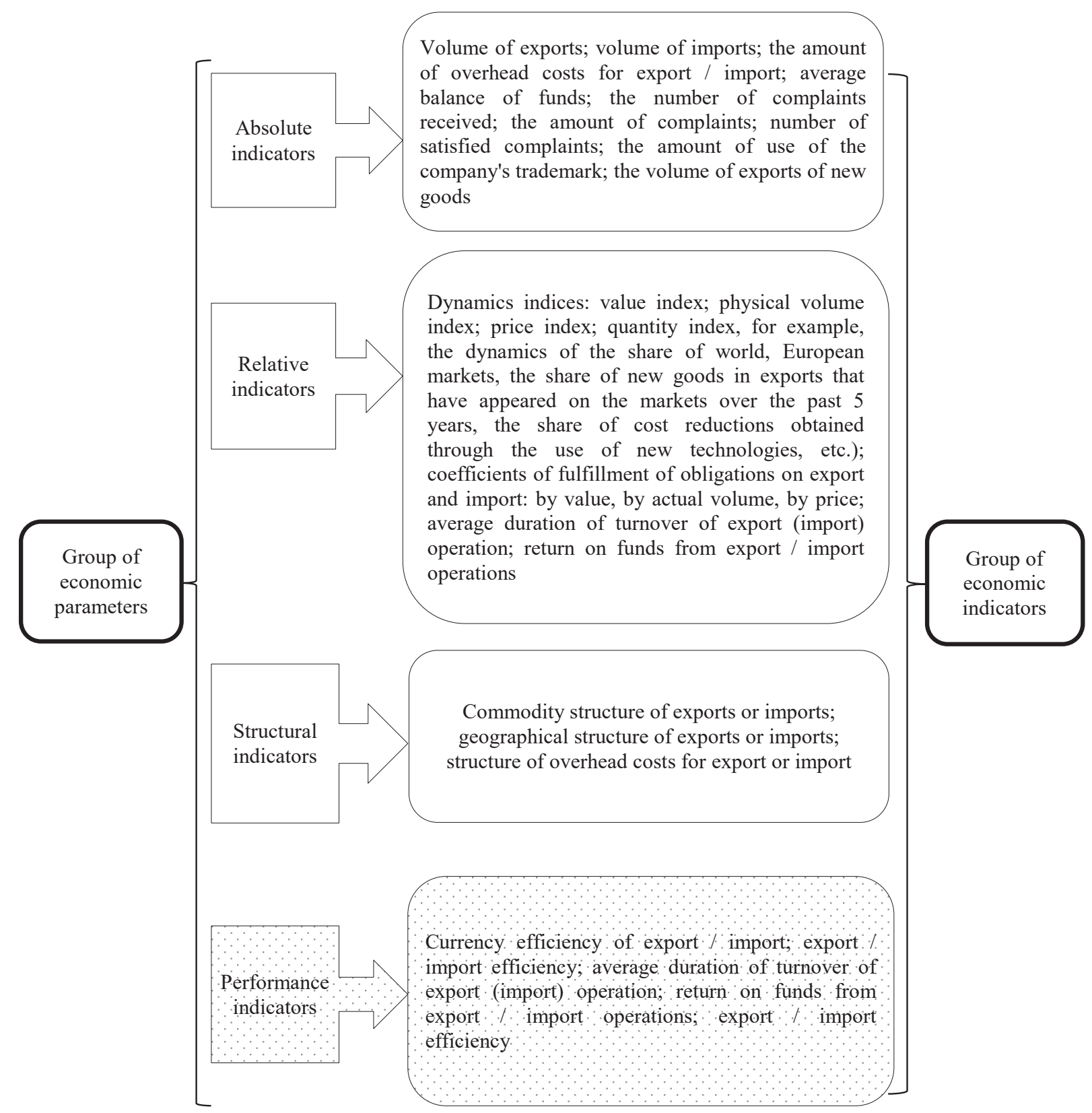

Figure 1. Indicators for determining the efficiency of business strategy in international trade of the enterprise in the subsystem of strategic management

Source: author's interpretation of performance indicators

- the level of export efficiency (the ratio of profits from export activities to the cost of products intended for export; demonstrates the profitability of export activities).

It is proposed to supplement it with indicators of the following block, which characterize the economic efficiency (result) of the business strategy in international trade:

1. Profitability of sales, which characterizes the level of profit derived from the currency of export sales $(\mathrm{PrS})$ :

$$
\operatorname{Pr} S=\frac{\text { Profit from sales for export }}{\text { Net revenue from sales for profit }} \cdot 100 \% \text {, }
$$

2. The ratio of growth in export earnings (Ip) with growth in export sales (Ies) and costs (Ic):

$I p>I e s>I c$,

where Ip is a profit index;

Ie is an export sales index;

Ic is a cost index.

Business activity of the subsystem of strategic management of the enterprise in business strategy in international trade is manifested in the dynamics of enterprise development, achievement of objectives, effective use of economic potential, expansion of markets. 


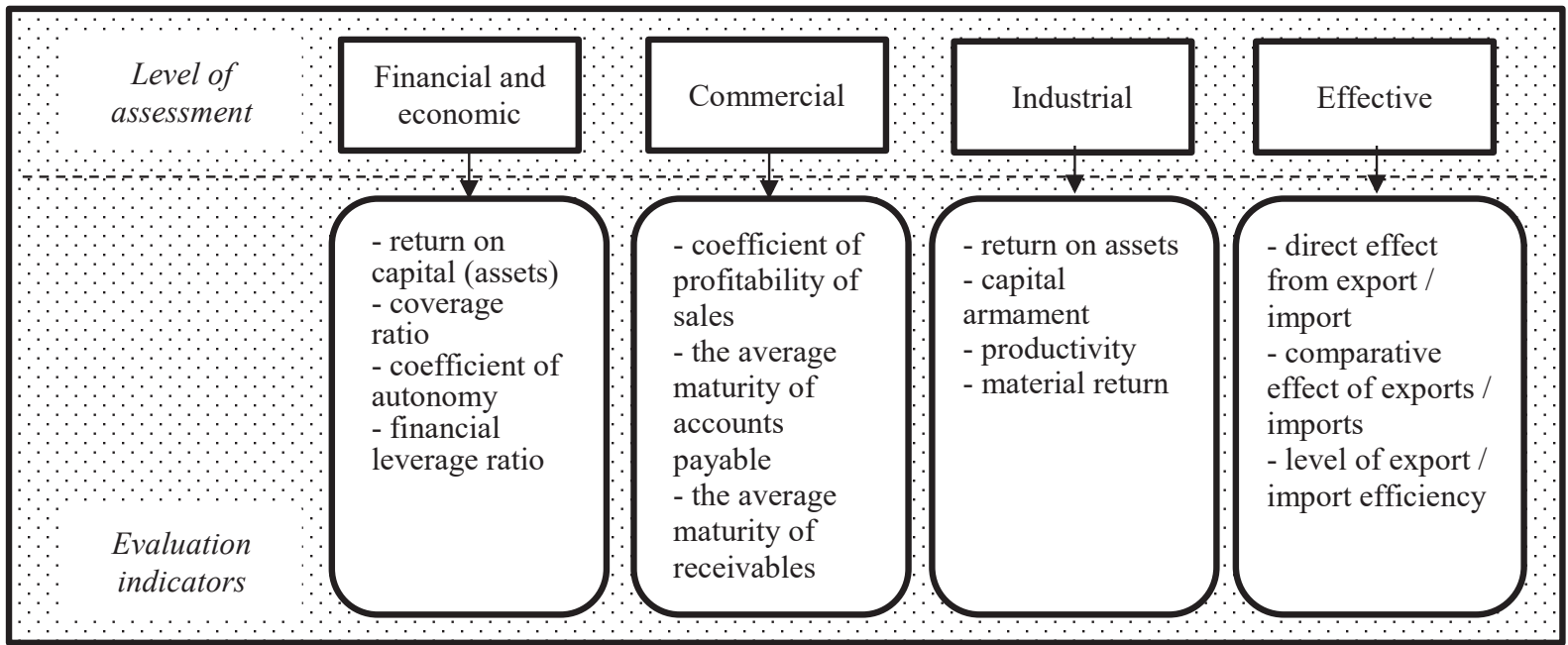

Figure 2. Indicators of efficiency in assessing the quality of business strategy in international trade

Source: supplemented by the author's indicators of efficiency and selection of levels

In particular, indicators of the level of efficiency of business strategy in international trade and the effectiveness of the used resource and financial support are offered:

- the level of exports in sales of the enterprise (Le):

$$
L e=\frac{\text { export }}{\text { sales volume }} \cdot 100 \% \text {, }
$$

- level of imports in the total volume of deliveries to the enterprise $(\mathrm{Li})$ :

$$
L i=\frac{\text { import }}{\text { volume of deliveries }} \cdot 100 \% \text {, }
$$

- the ratio of the cost of export products and the cost of products intended for sale in the domestic market (Rec):

$$
\operatorname{Rec}=\frac{\text { cost of exported products }}{\text { cost of products that will enter the domestic market }}(5)
$$

- the ratio of efficiency of sale of export goods (Ref):

$$
\text { Ref }=\frac{\text { net revenue from exported products }}{\text { cost of exported products }}
$$

- the level of cost of products exported in the total cost of goods sold (Lc):

$$
L c=\frac{\text { cost of exported products }}{\text { cost of goods sold }} \cdot 100 \%
$$

- the ratio of the cost of export products and export earnings $(\mathrm{Rc})$ :

$$
R c=\frac{\text { cost of exported products }}{\text { net revenue of exported products }}
$$

When assessing the strategic management of the enterprise in business strategy in international trade, along with generalizing indicators, the indicators characterizing the efficiency of certain types of costs (labour, energy, material, capital, etc.) can be calculated and differentiated. Therefore, it is necessary to evaluate the efficiency of the business strategy of the enterprise in international trade using a tool that can simultaneously calculate the effectiveness of the strategy depending on the significance of the goals, compare it with the benchmark and the level of economic risk and finally choose the most effective way to enter the foreign market. The use of this technique involves the assessment of current indicators in the following promising areas: production process (cost of goods sold; profitability of sales; transportation, tax costs, etc.); investments (research, planning and development of enterprise projects); innovations (improvement of innovation and operational processes at the enterprise); marketing aspects (market share, expansion and preservation of the customer base, the level of customer satisfaction); personnel (opportunities for workers and opportunities to use information systems); risks (assessment and minimization of possible risks) (Vasyuk, 2015).

\section{The efficiency of exports and imports as key indicators of the quality of business strategy in international trade}

The indicator "export efficiency" is determined by the ratio of net foreign currency earnings for goods sold converted to hryvnia at the official exchange rate on the day of receipt of foreign exchange earnings, to the value of exports in domestic prices. The value of the indicator is considered more than one and indicates that the sale of goods on the foreign market will be more profitable than within the country.

The indicator of the economic effect of exports is calculated by subtracting from the net revenue in foreign currency for goods sold converted to hryvnia at the official exchange rate on the day of receipt of foreign exchange earnings, the amount of total costs of the enterprise for export. In essence, this indicator is the 
company's profit from export activities before taxation, respectively, the greater its value, the more efficient export activities. In order to determine the dynamics of efficiency of sales in the reporting period, the indicators of export efficiency should be compared with similar indicators for the previous period. To determine the economic efficiency of export activities at the enterprise level, we propose to calculate three indicators of economic efficiency.

Analysing the efficiency of import operations, you must first know its currency efficiency. As for the indicator of foreign exchange efficiency of exports, as a rule, the exchange rate is the basis of comparison. The indicator of economic (absolute) efficiency of imports is calculated by dividing the value of imported products in the domestic market by the cost of purchasing imported products.

Among other goals of international trade there is the need to attract foreign goods in its own production. That is why the definition of economic efficiency of import activities of the enterprise involves the use of indicators of efficiency of imports of industrial goods for its own production activities. In the modern scientific literature in determining the effectiveness of imports of industrial products focuses on the effectiveness of the involvement in the production of imported equipment and facilities (Fedoronko, 2016).

Most often, indicators such as the absolute market share of the enterprise and the relative market share of the enterprise (defined as the ratio of the market share of the firm to the market share of the strongest market competitor) are used to assess the effectiveness of the current business strategy in international trade. If we are talking about forecasting the effectiveness of the business strategy of export activities, then indicators such as the absolute market share of the enterprise and the relative market share of the enterprise will have a forecast interest if the company has already carried out export activities in this market. The relative market share and its dynamics characterize the competitive position of the enterprise more objectively than the indicator of absolute market share.

In strategic management, responsible professionals need to process a fairly large array of information data. At the same time, it is important to establish cooperation between top management and other functional units of the enterprise. Having formed the company's own system of economic parameters to assess the quality of business strategy in international trade, management staff will be able to streamline the current and strategic actions for the development of export potential. Clearly defined priorities in the international trade of the enterprise, taking into account the specifics of its operation in the market and the limits of coverage of foreign markets, will guide top management to make effective management decisions.
To make the right decisions in strategic management to implement the right business strategy in international trade, it is important to study the financial and credit situation in the country, which indicators are interest rates, inflation, budget deficits, exchange rates, income distribution among certain social groups.

Analysis of foreign market conditions involves the calculation of forecast indicators: production of goods (supply); consumption (demand) (wholesale and retail trade, market capacity); currency and credit situations (exchange rates, discount rates, stock prices); prices as integrated indicators.

Strengthening integration in the development of international trade necessitates the consideration of globalization processes in strategic management, as one of a set of factors to improve the efficiency of foreign economic activity. In general, the most important parameter of international trade in foreign economic activity of the enterprise, in our opinion, is the implementation of strategic goals to expand markets, the organization of international cooperation on favourable terms for the company.

\section{System of parameters for assessing the level of quality of business strategy in international trade}

In our opinion, the main thing is to determine the functional principles of strategic control, the effectiveness of business strategy in international trade and the parameters that best determine the level of development of this activity in the strategic management system taking into account integration processes and the impact of globalization on international cooperation. Enterprises need to ensure an appropriate level of product competitiveness, find ways to grow it, implement strategies that will promote the development of financial and economic activities in modern conditions of operation and counteract adverse market factors.

In times of crisis, ensuring the implementation of certain strategic goals for the development of international trade is a difficult process for all enterprises without exception. The business entity that carefully approaches the formation of an appropriate effective mechanism of strategic management with a reliable justification of the tasks for the implementation of the chosen strategy is able to take a leading position in the competition not only in the current period, but also in the future. Accordingly, to assess the level of quality of business strategy in international trade, it is necessary to choose a system of parameters that should characterize the compliance of research results with the objectives. This system of parameters is presented in Table 1 .

In our opinion, the basic parameters are chosen in the system of parameters for assessing the level of quality of business strategy implementation in international 
Vol. 7 No. 2, 2021

Table 1

The system of parameters for assessing the level of quality of business strategy in international trade

\begin{tabular}{|l|l|}
\hline The name of the parameter & $\begin{array}{l}\text { The importance and scope of assessing the level of quality of business } \\
\text { strategy }\end{array}$ \\
\hline Assess the achievement of business strategy goals & $\begin{array}{l}\text { All planned goals achieved / Main planned goals achieved / Not all } \\
\text { planned goals achieved }\end{array}$ \\
\hline $\begin{array}{l}\text { The importance of information data from the evaluation of business } \\
\text { strategy }\end{array}$ & $\begin{array}{l}\text { Very high / High / Significant / Low / Very low / Virtually absent } \\
\text { (critical) }\end{array}$ \\
\hline Terms of business strategy evaluation & Early / On time / Delayed \\
\hline $\begin{array}{l}\text { Technical level of assessment } \\
\text { Methodological level of assessment }\end{array}$ & $\begin{array}{l}\text { Compliance with technical parameters / Used in research / } \\
\text { Technological innovations }\end{array}$ \\
\hline $\begin{array}{l}\text { Novelty of the received information for adjustment of business } \\
\text { strategy }\end{array}$ & $\begin{array}{l}\text { Correspondence of methodical approaches used in conducting } \\
\text { research with modern achievements of science }\end{array}$ \\
\hline
\end{tabular}

Source: author's generalizations

trade, but in the process of strategic management, they can be supplemented by top management of the enterprise, depending on the level of international trade intensification. It should be noted that management decisions made based on quality information obtained from strategic research, increase the level of certainty of the decision, minimize the risk of loss.

By analysing the financial and economic activities of the enterprise and determining the quality indicators of business strategy in international trade, taking into account the parameters of efficiency, top management will be able to form fundamental directions to strengthen competitive advantages, improve product quality to expand market external segments.

\section{Conclusions}

It is established that the assessment of the quality of the business strategy of the enterprise in international trade should be calculated when planning the exit or expansion of foreign markets not only taking into account absolute, relative and structural indicators, but also efficiency indicators.

Based on the fact that today there are a large number of possible indicators used to assess the level of efficiency of business strategy in international trade of enterprises outlined the problematic aspects faced by managers during the systematization of groups of indicators of business strategy in international trade: significant differentiation types of international trade leads to the presence of a significant number of indicators of processes in this area; the concept of the effectiveness of business strategy in the international trade of the enterprise is quite debatable and there is no single paradigm for interpretation; there are different methods of calculating the effectiveness of business strategy in international trade, based on the definition of several economic parameters (indicators) or involve the use of economic and mathematical modelling with appropriate software; there are no uniform methodological recommendations and approaches to the formation of a subsystem of indicators to assess the effectiveness of business strategy in international trade of economic entities.

Given the lack of a unified approach to determining the quality of business strategy in international trade on the basis of efficiency indicators, groups of indicators are proposed to analyse and evaluate the effectiveness of foreign economic activity that can be used in management; indicators of the level of efficiency of international trade and the effectiveness of its used resource and financial support, which should be calculated in the implementation of export-import operations.

To determine the quality of business strategy in international trade, the feasibility of using the main block of efficiency indicators such as: direct effect of exports / imports, comparative effect of exports / imports, the level of efficiency of exports / imports, and supplementing the block of indicators characterizing economic efficiency (end result) of business strategies in international trade, in particular such as: profitability of sales, which characterizes the level of profit derived from the currency of export sales and the ratio of growth of export earnings to the growth of export sales and costs.

In order to overcome information asymmetry and minimize time for processing large arrays of input data, it is proposed to form the company's own system of economic parameters to assess the quality of business strategy in international trade, which will allow management to streamline current and strategic actions to develop export and import potential. The following basic parameters include: assessment of the scope of achieving business strategy goals, the importance of information data from the assessment of business strategy, timing of assessment of business strategy, technical and methodological level of assessment, novelty of information obtained to adjust business strategy. 


\section{References:}

David, B. Yoffie, \& Michael A. Cusumano (2015). Strategy rules. Five timeless lessons from Bill Gates, Andy Grove, and Steve Jobs. New York: HarperBusiness, 254 p.

Chandler, A. (2001). Strategy and structure. Moscow: Marketing, 312 p.

Christensen, Clayton M., \& Bower, Joseph L. (1995). Disruptive technologies: catching the wave. New York: Harvard Business Review.

Ansoff, I. (1989). Strategic Management. Moscow: Economics, 519 p.

Porter, M. (1980). Competitive Strategy: Techniques for Analyzing Industries and Competitors. NY: Free Press.

Treacy, M., \& Wiersema, F. (1995). The Discipline of Market Leaders. Reading. Boston: Addison-Wesley.

Mintzberg, H. (1992). Five Ps for Strategy. Englewood Cliffs NJ, Prentice-Hall International Editions.

Hamel, G., \& Prahalad, C. (1994) Competing for the Future. Boston: Harvard Business School Press.

Thompson, A. (2007). Strategic Management: Concepts and Situations for Analysis. Moscow: Williams Publishing House, $928 \mathrm{p}$.

Khomenko, T., \& Krush, P. (2019). Methodical approaches to the assessment of the effectiveness of foreign economic activity management. Current problems of economics and management: a collection of scientific works of young scientists, vol. 11. Available at: http://ela.kpi.ua/handle/123456789/22596

Shkvarchuk, L., \& Byrka, I. (2013). Estimation of economic efficiency of foreign economic activity of the enterprise. Bulletin of the National University «Lviv Polytechnic», vol. 769, pp. 196-201.

Vasyuk, T. (2015). Methods of research and determination of economic efficiency of foreign economic activity of economic entities. Current economic problems, vol. 3, pp. 131-136.

Fedoronko, N. (2016). Analysis of the effectiveness of export and import operations. Global and National Economic Problems, vol. 10, pp. 120-123. 